\title{
PENGARUH TATA KELOLA PERUSAHAAN TERHADAP MANAJEMEN RISIKO PADA PERBANKAN INDONESIA
}

\author{
Ajeng Andriani Hapsari ${ }^{1}$ \\ ${ }^{1}$ Fakultas Bisnis dan Manajemen, Universitas Widyatama Bandung \\ Email:ajeng.andriani@widyatama.ac.id
}

\begin{abstract}
ABSTRAK
Melaksanakan tata kelola perusahaan yang baik bagi perusahaan merupakan hal yang sangat penting, terutama untuk perusahaan perbankan. Penelitian ini untuk menguji pengaruh tata kelola perusahaan yang baik terhadap manajemen risiko perusahaan perbankan di Indonesia kurun waktu 2011-2016. Penelitian ini merupakan penelitian yang bersifat deskriptif verifikatif, dengan Teknik purposive sampel, dengan metode pengumpulan data menggunakan model data panel. Hasil yang diperoleh tidak ada satupun dari varibel GCG yang berpengaruh secara signifikan terhadap return saham yang dalam hal ini menjadi variable manajemen risiko perusahaan.
\end{abstract}

Kata kunci: tuliskan 3-5 kata kunci yang terkait dengan isi makalah

\section{PENDAHULUAN}

\section{Latar Belakang}

Lembaga perbankan sebagai salah satu lembaga keuangan yang mempunyai nilai yang sangat strategis dalam kehidupan perekonomian suatu Negara. Lembaga tersebut dimaksudkan sebagai perantara pihak-pihak yang mempunyai kelebihan dana (surplus of fund) dengan pihak-pihak yang kekurangan dana atau membutuhkan dana (lack of fund). Hal tersebut mengakibatkan risiko pada sector perbankan itu sendiri, melalui Peraturan Bank Indonesia No. 5/8/PBI/2003 tanggal 19 Mei 2003 Bank Indonesia memperlihatkan keseriuasannya dengan mengeluarkan Penerapan Manajemen Risiko untuk Bank Umum. Selanjutnya dipertegas lagi dengan mengeluarkan Peraturan Bank Indonesia No. 7/25/PBI/2005 pada bulan Agustus 2005 tentang Sertifikasi Manajemen Risiko bagi Pengurus dan Pejabat Bank Umum dari tingkat terendah hingga tertinggi sesuai dengan tingkat jabatannya. Selain kedua peraturan tersebut, dilengkapi pula Peraturan Bank Indonesia No. 8/4/PBI/2006 yang disempurnakan tentang pelaksanaan Good Corporate Governance bagi Bank Umum, yang didalamnya menunjukan keseriusan Bank Indonesia dalam menerapkan manajemen risiko guna melindungi kepentingan stakeholder. Seperti yang terlihat pada Gambar 1.1 tentang perkembangan GCG di Indonesia selama 6 tahun yang terus mengalami peningkatan.

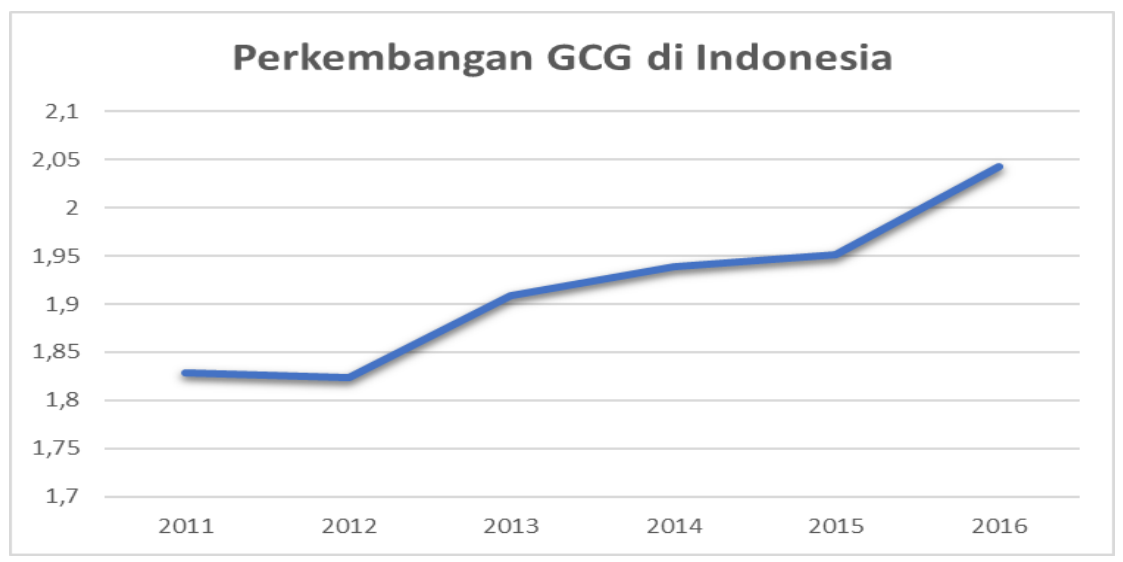

Gambar 1. Perkembangan GCG di Indonesia 
Krisis ekonomi ditahun 1997 merupakan awal mula Corporate Governance banyak dibicarakan dan mulai diterapkan di Asia, krisis yang melanda sebagian besar wilayah dunia juga Negaranegara di Asia Timur termasuk Indonesia dikarenakan masalah fundamental yang ada didalam struktur ekonomi tiap Negara. Selain dari pihak eksternal, terjadinya krisis juga disebabkan oleh aspek internal seperti kurangnya pengawasan didalam kelembagaan dan juga keputusan investasi yang kurang tepat (Harahap, 2003). Seperti yang disebutkan Daniri, 2005 bahwa terjadinya krisis ekonomi dikarenakan lemahnya penerapan prinsip Corporate Governance. Pendapat lain dikatakan oleh Herwidayatmo (2000) dan Muntoro (2006) diduga bahwa salah satu penyebab terjadinya krisis di Indonesia adalah lemahnya pengawasan yang dilakukan terhadap direksi perusahaan yang seharusnya menjadi tanggung jawab dari Dewan Komisaris.

Penerapan GCG juga merupakan suatu tuntutan agar perusahaan- perusahaan yang ada tidak sampai terlindas oleh persaingan global yang semakin keras. Karena, pada dasarnya prinsipprinsip dasar dari GCG mempunyai tujuan untuk memberikan kemajuan terhadap kinerja suatu perusahaan yang lebih condong kepada serangkaian pola perilaku perusahaan yang diukur dengan kinerja, pertumbuhan, struktur pembiayan, perlakuan terhadap para pemegang saham, dan juga stakeholders yang dapat menjadikan sebagai dasar analisis dalam mengkaji corporate governance disuatu perusahaan dengan memenuhi transparansi dan akuntabilitas didalam pengambilan keputusan yang sistematis yang dapat digunakan sebagai dasar pengukuran yang lebi akurat mengenai kinerja perusahaan. Seperti hasil riset dari The Indonesian Institute for Corporate Governance (IICG) tahun 2002 ditemukan bahwa alasan utama perusahaan menerapkan GCG adalah kepatuhan terhdap peraturan, karena perusahaan meyakini bahwa implementasi GCG merupakan bentuk lain penegakan etika bisnis dan etika kerja yang sudah lama menjadi komitmen perusahaan, dan implementasi GCG berhubungan dengan peningkatan citra perusahaan. Sehingga, perusahaan yang mempraktikan GCG akan mengalami perbaikan citra dan peningkatan nilai perusahaan.

Didukung dengan penelitian yang telah dilakukan oleh Brown dan Caylor (2004) juga Arcay dan Va'zquez (2005) mengatakan bahwa penerapan Good Corporate Governance didalam menjalankan suatu perusahaan diharapkan mampu membuat kinerja perusahaan menjadi lebih baik dan juga lebih transparan didalam memberikan inforamsi yang dibutuhkan oleh pasar. Selain itu Siagian (2011) mengatakan bahwa Corporate Governance diprediksi dapat meminimalisir Agency Problem yang ada diperusahaan, karena GCG akan meningkatkan komunikasi diantara manager dan para pemegang saham, meningkatkan peran dewan komisaris dan direksi dan komite-komite independen, melindungi kepentingan para pemegang saham minoritas dan juga dapat meningkatkan nilai perusahaan. Dan juga didalam beberapa kasus system remunerasi perusahaan tidak sejalan dengan strategi, risk appetite, dan kepentingan jangka panjang yang dimiliki perusahaan. Sehingga, pada penelitian tersebut memberikan rekomendasi akan pentingnya kualitas board oversight dan juga manajemen risiko suatu perusahaan sebagai suatu bagian dari penerapan GCG.

Selain itu ada kewajiban bank untuk melakukan penelitian sendiri (Self Assessment) tingkat kesehatan bank dengan menggunakan pendekatan Risiko (Risk Based Bank Rating/RBBR) baik individual maupun secara konsolidasi yang antara lain mencangkup penilaian faktor Good Corporate Governance ( $G C G$ ) sebagaimana dimaksud dalam Peraturan Bank Indonesia Nomer 13/1/PBI/2011 tentang Penilaian Tingkat Kesehatan Bank Umum (Lembaran Negara Republik Indonesia tahun 2011 Nomor 1, Tambahan Lembaran Negara Republik Indonesia Nomor 5184), 
Peraturan Bank Indonesia Nomor 8/4/PBI/2006 tentang pelaksanaan Good Corporate Governance bagi Bank Umum.

Topik utama didalam tata kelola perusahaan adalah masalah akuntabilitas dan tanggung jawb mandate yang ada diperusahaan khususnya implementasi pedoman dan mekanisme didalam memastikan perilaku yang baik serta melindungi kepentingan dari para pemegang saham. Selain itu, focus pada efisiensi ekonomi yang menyatakan bahwa system tata kelola perusahaan harus ditujukan untuk mengoptimalisasi hasil ekonomi, dengan penekanan yang kuat pada kesejahteraan para pemegang saham. Salah satu solusi bagi para pemegang saham adalah manajemen risiko, menurut Bank Indonesia sendiri manajemen risiko merupakan prosedur dan metodologi yang digunakan untuk mengidentifikasi, memantau dan mengendalikan risiko yang timbul dalam setiap kegiatan usaha bank (Tampubolon, 2004). Salah satu tujuan dari manajemen risiko adalah menciptakan nilai dari para pemegang saham, yang selalu akan berkaitan dengan return saham perusahaan. Besarnya reaksi dari penurunan return saham terhadap factor yang mendasari return saham itu sendiri disebut dengan sensivitas saham (Brigham dan Ehrhard, 2013). Selain itu, sensivitas saham juga dipengaruhi oleh risiko lain yaitu risiko saham dan risiko operasional. Risiko pasar dilihat dari perubahan return saham.

\section{Tinjauan Pustaka}

Sesuai dengan Peraturan Bank Indonesia Nomor 13/1/PBI/2011 tentang Penilaian Tingkat Kesehatan Bank Umum (Lembaran Negara Republik Indonesia Tahun 2011 Nomor 1, Tambahan Lembaran Negara Republik Indonesia Nomor 5184), Peraturan Bank Indonesia Nomor 8/4/PBI/2006 tentang Pelaksanaan Good Corporate Governance bagi Bank Umum (Lembaran Negara Republik Indonesia Tahun 2006 Nomor 6, Tambahan Lembaran Negara Republik Indonesia Nomor 4600) sebagaimana telah diubah dengan Peraturan Bank Indonesia Nomor 8/14/PBI/2006 (Lembaran Negara Republik Indonesia Tahun 2006 Nomor 71, Tambahan Lembaran Negara Republik Indonesia Nomor 4640) dan Peraturan Bank Indonesia Nomor 8/6/PBI/2006 tentang Penerapan Manajemen Risiko bagi Bank Yang Melakukan Pengendalian terhadap Perusahaan Anak (Lembaran Negara Republik Indonesia Tahun 2006 Nomor 8, Tambahan Lembaran Negara Nomor 4602), perlu diatur kembali mengenai pelaksanaan Good Corporate Governance bagi Bank Umum dalam Surat Edaran Bank Indonesia.

Dalam rangka memastikan penerapan 5 (Lima) prinsip dasar GCG yaitu TARIF (Transparency, Accountability, Responsibility, Independency, and Fairness), maka Bank harus melakukan penilaian sendiri (self Assessment) secara berkala yang meliputi 11 faktor Penilaian Pelaksanaan GCG yaitu:

1. Pelaksanaan tugas dan tanggung jawab Dewan Komisaris;

2. Pelaksanaan tugas dan tanggung jawab Direksi;

3. Kelengkapan dan pelaksanaan tugas Komite;

4. Penanganan benturan kepentingan;

5. Penerapan fungsi kepatuhan;

6. Penerapan fungsi audit intern;

7. Penerapan fungsi audit ekstern;

8. Penerapan manajemen risiko termasuk sistem pengendalian intern;

9. Penyediaan dana kepada pihak terkait (related party) dan penyediaan dana besar (large exposures);

10. Transparansi kondisi keuangan dan non keuangan Bank, laporan pelaksanaan GCG dan pelaporan internal; dan

11. Rencana strategis Bank. 
Peraturan Bank Indonesia No.5 /8/PBI/2003 pada tanggal 19 Mei 2003 tentang Penerapan Manejemen Risiko Untuk Bank Umum, merupakan wujud keseriusan bank indonesia dalam masalah manjemen risiko perbankan. Keseriusan tersebut lebih dipertegas dengan dikeluarkannya Peraturan Bank Indonesia No.7/25/PBI/2005 pada bulan Agustus 2005 tentang Sertifikasi Manajemen Risiko bagi Pengurus dan Pejabat Bank Umum, yang mengharuskan seluruh pejabat bank dari tingkat terendah hingga tertinggi untuk memiliki sertifikasi manajemen risiko yang sesuai dengan tingkat jabatannya. Didalamnya dijelaskan bahwa manajemen risiko adalah serangkaian dari prosedur juga metodologi yang digunakan untuk mengidentifikasi, mengukur, memantau, dan mengendalikan risiko yang timbul dari kegiatan usaha bank. Dengan tujuan menciptakan nilai dari pemegang saham (Pagano, 2001), penciptaan ini selalu berkaitan dengan return saham perusahaan. Konsep risiko didalam perusahaan tidak terlepas dari kaitannya dengan return saham, karena investor selalu mengharapkan tingkat return yang sesuai atas setiap risiko investasi yang telah dilakukannya, return saham sendiri merupakan penghasilan yang diperoleh selama periode investasi per sejumlah dana yang diinvestasikan kedalam bentuk saham.

Mencari atau menghitung return saham suatu perusahaan dilakukan dengan cara membagi data harga saham suatu periode dibagi dengan periode sebelumnya.

\section{Return= $($ Pt-Pt-1)/Pt-1}

Dimana Pt adalah harga saham periode ke t- dan

$\mathrm{Pt}_{-1}$ adalah harga saham periode sebelumnya (t-1).

\section{Kerangka Penelitian}
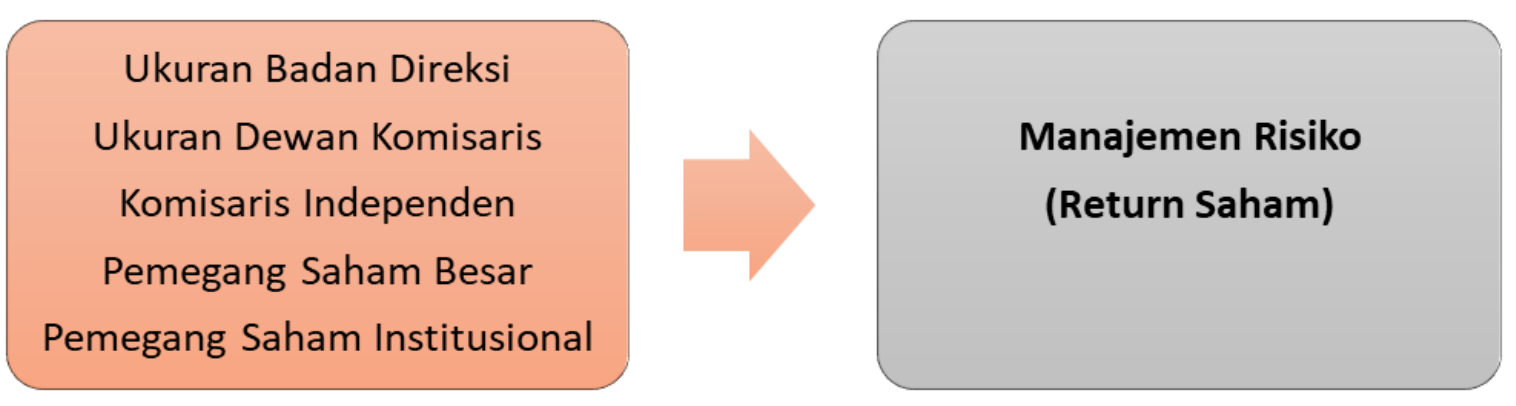

Gambar 2. Kerangka Penelitian

\section{METODE PENELITIAN}

Metode yang digunakan pada penelitian ini adalah metode Deskriptif Verifikatif. Metode ini digunakan didalam penelitian untuk mengetahui dari karakter tiap variable yang diteliti didalam suatu keadaan. Tujuan digunakannya metode deskriptif didalam penelitian ini adalah untuk memberikan gambaran dari aspek-aspek yang sesuai dengan suatu kejadian dari sudut pandang seseorang, organisasi dan lain-lain (Sugiyono, 2013). Metode sampling yang digunakan didalam 
penelitian ini adalah Teknik Purposive sampling, yang merupakan Teknik pengambilan sampel dengan pertimbangan tertentu (Sugiyono, 2013). Proses penentuan sampel sesuai dengan kriteria yang ditentukan yaitu bank yang terdaftar Di Bursa Efek selama periode 2011 sampai dengan 2016 dan mempunyai laporan publikasi laporan tahunan yang lengkap.

Teknik analisis dara yang digunakan didalam penelitian ini adalah Analisis Regresi Data Panel. Data Panel merupakan kombinasi antara data Cross Setion dan Time Series yang dapat memebrikan jumlah data yang lebih banyak, sehingga bisa memberikan Degree of Freedom yang lebih besar pula.

\section{HASIL DAN PEMBAHASAN}

Tabel 1. Hasil Regresi Linier Ouput Eviews

\begin{tabular}{ccccc} 
Variable & Coefficient & Std. Error & t-Statistic & Prob. \\
& & & & \\
\hline \hline C & 0.595798 & 0.319410 & 1.865307 & 0.0641 \\
BOD & -0.001630 & 0.022317 & -0.073041 & 0.9419 \\
BOC & -0.039207 & 0.034618 & -1.132571 & 0.2592 \\
INDIE & -0.452677 & 0.411765 & -1.099358 & 0.2734 \\
LARGE & 0.325253 & 0.305734 & 1.063843 & 0.2891 \\
INSTITUT & -0.296153 & 0.278113 & -1.064863 & 0.2886 \\
\hline \hline
\end{tabular}

Effects Specification

S.D. Rho

\begin{tabular}{lll}
\hline \hline Cross-section random & 0.000000 & 0.0000 \\
Idiosyncratic random & 0.523218 & 1.0000 \\
\hline
\end{tabular}

Weighted Statistics

\begin{tabular}{lclc}
\hline \hline R-squared & 0.035708 & Mean dependent var & 0.134998 \\
Adjusted R-squared & 0.003565 & S.D. dependent var & 0.506847 \\
S.E. of regression & 0.505943 & Sum squared resid & 38.39671 \\
F-statistic & 1.110910 & Durbin-Watson stat & 2.105535 \\
Prob(F-statistic) & 0.357032 & &
\end{tabular}




\begin{tabular}{llll}
\hline \hline \multicolumn{4}{l}{ Unweighted Statistics } \\
\hline \hline R-squared & 0.035708 & Mean dependent var & 0.134998 \\
Sum squared resid & 38.39671 & Durbin-Watson stat & 2.105535 \\
& & & \\
\hline \hline
\end{tabular}

Sumber: Hasil Olahan Penulis Menggunakan Eviews 7

Dari persamaan diatas, dapat kita lihat nilai koefisien untuk variable ukuran badan direksi $\mathrm{X}_{1}$ sebesar -0,001630, Ukuran Dewan Komisaris $X_{2}$ sebesar -0,039207, Komisaris Independen 0,452677, Pemegang Saham Besar 0,325253, Pemegang Saham Institusional -0,296153. Hanya Pemegang Saham Besar yang berpengaruh positif terhadap return saham. Sisanya berpengaruh negative terhadap return saham.

Intercep (C) 0.595798 merupakan nilai rata-rata dari komponen kesalahan random (random error component). Nilai random effect ini menunjukan seberapa besar perbedaan komponen kesalahan random sebuah perusahaan terhadap nilai intersep semua perusahaan (rata-rata).

Dari hasil analisis regresi yang dilakukan didapatkan data sebagai berikut:

- $\mathrm{R}-$ Squared $=0,035798$, yang menunjukan kemampuan model, variable independen yang menjelaskan pengaruhnya sebanyak $3.5798 \%$ terhadap variable dependen penelitian

- Adjusted $R$-squared $=0.003565$; merupakan nilai $\mathrm{R}^{2}$ yang sudah disesuaikan. Semakin banyak variable independen yang dimasukan kedalam persamaan akan memperkecil nilai tersebut.

- S.E. of Regression $=0.505943$; merupakan standar eror dari persamaan regresi.

- Sum Squared Residual = 38,39671 yang merupakan jumlah dari nilai residual dari kuadrat pada penelitian.

- Durbin-Watson Stat $=2.105535$; nilai uji Durbin Watson $(D W)$ yang digunakan untuk mengetahui apakah ada autokorelasi (hubungan antar residual) atau tidak pada penelitian ini.

- Mean Dependent Var $=0.134998$; nilai rata-rata variable dependen yang didalam hal ini adalah Manajemen Risiko.

- S.D. Dependent variable $=0.506847$; merupakan standar deviasi atau simpangan baku yang menunjukan standar penyimpangan terhadap variable $\mathrm{Y}$.

- F-Statistics $=1.110910 ;$ merupakan uji serempak dari semua pengaruh variable independen terhadap variable dependen.

- $\operatorname{Prob}($ F-Statistics $)=0.357032$ merupakan probabilitas nilai uji statistic F.

\section{Koefisien Determinasi $\mathbf{R}^{2}$}

Uji statistic model berkaitan dengan statistic yang digunakan untuk melihat seberapa baik model atau variable yang digunakan didalam suatu penelitian. Kriteria statistic tersebut tergantung dari beberapa nilai atau parameter yang diuji dengan uji statistic. 
Nilai $\mathrm{R}^{2}$ merupakan suatu nilai yang menunjukan seberapa baik model regresi yang digunakan didalam suatu penelitian. Seperti yang dituliskan Nachrowi dan usman (2006), $\mathrm{R}^{2}$ sangatlah berguna untuk mengukur "kedekatan" anatara nilai prediksi dan nilai sesungguhnya pada variable terikat. Nilai $\mathrm{R}^{2}$ berada dalam kisaran $0<\mathrm{R}^{2}<1$, jadi apabila mendekati nol atau 0 , maka variable terikat menjadi semakin tidak bisa dijelaskan oleh variable-variabel bebas yang digunakan didalam penelitian. Sebaliknya, jika mendekati 1, maka model regresi yang digunakan semakin baik, sementara nilai Adjusted $R^{2}$ ditujukan untuk memperkuat daya prediksi suatu model.

Tabel 3. Nilai $\mathrm{R}^{2}$ dan Adjusted $\mathrm{R}^{2}$

Sumber: Hasil Olahan Penulis menggunakan Eviews7

\begin{tabular}{|l|c|}
\hline R-squared & 0.035708 \\
\hline Adjusted R-squared & 0.003565 \\
\hline
\end{tabular}

Berdasarkan tabel 3 diatas, terlihat bahwa $\mathrm{R}^{2}$ sebesar 3,57\% yang berarti bahwa return saham sebagai variable dependen didalam penelitian ini dapat dijelaskan hanya sebesar $3,57 \%$ oleh model, sedangkan 96,43\% dijelaskan oleh factor-faktor yang lain diluar model. Variable Ukuran Badan Direksi, Ukuran Dewan komisaris, Komisaris Independen, Pemegang Saham Besar, dan Pemegang Saham institusional hanya mampu menjelaskan pengaruhnya sebesar 3,57\% terhadap variable dependen.

\section{Signifikansi Linier Berganda ( $F$-Stat)}

Nachrowi dan Usman (2006) menyatakan bahwa Uji-F diperuntukan guna melakukan uji hipotesis koefisien (slope) regresi secara bersamaan.

Tabel 4 Ringkasan F-stat dan Prob. F-stat

\begin{tabular}{llll}
\hline F-statistic & Prob(F-statistic) & Significant & Hipotesis \\
\hline $\mathbf{1 , 1 1 0 9 1 0}$ & 0.357032 & Tidak Signifikan* & $\mathrm{H}_{0}$ ditolak \\
\hline
\end{tabular}

Keterangan: *menunjukan tingkat signifikansi pada level 5\%

Sumber: Hasil Olahan Penulis menggunakan Eviews7

Dari tabel 4 diatas dijelaskan bahwa nilai F-stat adalah sebesar 1,110910 dengan probabilitas 0,357032, yang artinya >0,05 maka dapat disimpulkan bahwa variable-variabel independen mempunyai pengaruh yang tidak signifikan terhadap return saham. Karena signifikansi lebih dari 0,05 maka hipotesis alternative tidak dapat ditolak. Dengan kata lain tidak ada satu pun variable bebas yang mempunyai pengaruh terhadap variable terikat/dependen.

\section{Signifikansi Parsial (T-stat)}

Uji t ini digunakan untuk mengetahui apakah secara individu variable-variabel independen (Ukuran Badan Direksi, Ukuran Dewan Komisaris, Komisaris Independen, Pemegang Saham Besar dan Pemegang Saham Institusional) yang digunakan berpengaruh secara signifikan terhadap variable dependennya return saham, Uji t dilakukan dengan cara membandingkan nilai probabilitas t-statistik ( $p$-value) dengan signifikansi $(\alpha)$. Kriteria keputusan tolak $\mathrm{H}_{0}$ bila $p$-value $<\alpha$. Berdasarkan hasil perhitungan yang telah dilakukan, kesimpulan dari hasil penelitian adalah sebagai berikut 
1. Variable ukuran Badan Direksi mempunyai nilai probabilitas sebesar 0,9419>0,05, maka sesuai dengan ketentuan bahwa Ukuran dewan Direksi tidak berpengaruh secara signifikan terhadap return saham

2. Variable Ukuran Dewan Komisaris mempunyai nilai probabilitas sebesar 0,2592 > 0,05, maka sesuai dengan ketentuan bahwa Ukuran Dewan komisaris tidak berpengaruh secara signifikan terhadap return saham

3. Variable Komisaris Independen mempunyai nilai probabilitas sebesar 0,2734 > 0,05, maka sesuai dengan ketentuan bahwa Komisaris Independen tidak berpengaruh secara signifikan terhadap return saham

4. Variable Pemegang Saham Besar mempunyai nilai probabilitas sebesar 0,2891>0,05, maka sesuai dengan ketentuan bahwa Pemegang Saham Besar tidak berpengaruh secara signifikan terhadap return saham

5. Variable Pemegang Saham Institusional mempunyai nilai probabilitas sebesar 0,2886 > 0,05, maka sesuai dengan ketentuan bahwa Ukuran dewan Direksi tidak berpengaruh secara signifikan terhadap return saham

Berdasarkan hasil pengujian yang dilakukan, Ukuran Badan Direksi mempunyai pengaruh yang negative dan tidak signifikan terhadap Return Saham perusahaan. Hasil tidak signifikan pada variable Ukuran Badan Direksi disebabkan karena return saham perusahaan tidak mempunyai pengaruh terhadap return saham perusahaan. Ukuran Dewan Komisaris yang cukup banyak menyebabkan perbedaaan pendapat yang cukup besar antara dewan direksi yang ada, sehingga sulit untuk melakukan analisis Fundamental maupun teknikal yang diperlukan untuk mengukur nilai saham perusahaan.

Ukuran dewan komisaris mendapatkan hasil yang negative dan tidak signifikan terhadap return saham. Didapatkan data bahwa ukuran dewan komisaris didalam perbankan sangat banyak, tetapi tidak memberikan pengaruh yang baik terhadap return saham perusahaan. Dikarenakan pengawasan dari dewan komisaris tidak dilakukan secara menyeluruh. Sehingga kinerja dari return saham perusahaan tidak semakin membaik karena pengawasan yang kurang.

Komisaris independen mempunyai pengaruh yang negative dan tidak signifikan terhadap return saham. Komisaris Independen perbankan ternyata tidak memberikan pengaruh pada return saham perusahaan. Berdasarkan data statistic deskriptif yang didapatkan, rata-rata jumlah dewan komisaris yang telah ditetapkan oleh aturan perundang-undangan yaitu 30\% Komisaris Independen, tetapi ternyata hal ini tidak memberikan dampak pada return saham perusahaan.

Pemegang saham besar mempunyai pengaruh yang positif namun tidak signifikan terhadap return saham perusahaan. Dapat kita ketahui bahwa seberapa banyak seorang pemilik perusahaan atau suatu perusahaan mendominasi kepemilikan saham perusahaannya tidak berpengaruh pada besarnya return saham yang dimiliki perusahaan tersebut.

Pemegang saham institusional mempunyai pengaruh yang positif namun tidak signifikan terhadap return saham perusahaan. Seharusnya semakin besar saham yang dimiliki oleh suatu institusi membuat return saham perusahaan menjadi semakin baik, dikarenakan tingginya control terhadap kinerja perusahaan. 


\section{KESIMPULAN DAN SARAN}

\section{Kesimpulan}

Bagi perusahaan perbankan, melaksanakan Good Corporate Governance adalah suatu keharusan, dengan banyaknya peraturan yang dikeluarkan oleh Bank Indonesia dan Otoritas Jasa Keuangan mengenai hal ini. Dari hasil penelitian yang dilakukan, tidak ada satupun variable GCG (Ukuran Badan Direksi, ukuran Dewan Komisaris, Komisaris Independen, Pemegang Saham Besar, dan Pemegang Saham Institusional) yang berpengaruh secara signifikan terhadap manajemen risiko perusahaan baik secara simultan maupun parsial, yang dalam hal ini diwakili oleh variable return saham. Ini dikarenakan kepemilikan manajemen perusahaan perbankan di Indonesia masih sangat rendah, sehingga pada praktiknya para pihak manajemen perusahaan di Indonesia lebih cenderung lebih banyak bertindak untuk memaximalkan utilitasnya sendiri dibandingkan focus untuk memberikan kinerja yang baik untuk perusahaan, yang pada akhirnya malah berakibat merugikan para pemegang saham. Selain itu, dimungkinkan praktek GCG diperusahaan memang dilaksanakan tetapi, implementasinya masih belum diterapkan dengan baik oleh perusahaan. Atau dengan kata lain GCG perbankan di Indonesia masih dijalankan hanya sekedar formalitas saja.

\section{Saran}

\section{Bagi Pihak Praktisi}

Bagi Pemerintah, sebaiknya pemerintah melakukan terobosan dengan membuat aplikasi untuk mempermudah peninjauan dan pemantauan dari setiap variable control yang ada dari GCG. Dengan kemajuan teknologi tersebut pemerintah, perusahaan dan stakeholder bisa mempermudah perusahaan untuk mencari tahu aspek GCG yang belum dijalankan dengan baik.

\section{Bagi Pihak Akademisi}

Sebaiknya menggunakan variable yang jauh lebih representative dan up to date dengan mencari dan menambahkan variable baru yang lebih logis pada penelitian. Sejalan dengan perkembangan teknologi yang lebih modern dan praktis, ada baiknya GCG masuk kedalam Fintech yang merupakan inovasi keuangan era digital saat ini. Ada baiknya pihak akademisi juga menggunakan metode dan alat statistic lain didalm menganalisis dan mengolah datanya.

\section{REFERENSI}

Brigham, EF and Lc Gapensi. 2002. Intermediate Financial Management, Fith Edition, The Drysden Press, New York.

Brown, dan Caylor .2004. Corporate Governance and firm performance.

Harahap, Sofyan Safri, 2003. Teori Akuntansi, Edisi Kelima, PT. Raspindo, Jakarta.

Herwidayatmo. 2000. Implementasi Good Corporate Governance Untuk Perusahaan Publik di Indonesia. Usahawan No. 10 TH XXIX Oktober.

Gujarati, D. 2003. Ekonometrika Dasar. Erlangga. Jakarta.

Muntoro, R.K. 2006. Profesionalisme Akuntan Manajemen Economic Business Accounting Review, II April 2006. Indonesia.

OECD. (2015). G20/OECD Principles of Corporate Governance. OECD Report to G20 Finance Ministers and Central Bank Governors.

Pagano, Michael S. 2001. How Theories of Financial Intermediation and Corporate Risk Management Influence Bank Risk Taking Behavior. Volume 10, Issue 5. December 2001 
Siagian, Ferdinand., et.,al. 2011. Corporate Governance, Reporting Quality, and Firm Value: Evidence from Indonesia. ISSN: 2042-1168. Emeraldinsight. Journal of Accounting In Emerging Economies Volume 3, Issue 1

Sugiyono, P. D. (2013). Metode Penelitian Bisnis. Bandung: Alfabeta.

Solomon, Jill. (2010). Coporate Governance and Accountability. Third Edition. The Atrium, Southern Gate, Chichester England: John Wiley \& Sons Ltd.

Widarjono, Agus. (2013). Ekonometrika: Pengantar dan Aplikasinya Disertai Panduan EViews. Yogyakarta: UPP STIM YKPN. 